\title{
Does Protein Intake Affect Metabolic Risk Factors among Older Adults in Korea?
}

\author{
Chorong Oh, Jaekyung No* \\ Department of Food and Nutrition, Kyungsung University, Busan, Korea
}

Background: Carbohydrate intake can impact metabolic risk factors, but related research on protein intake in the elderly is rare. Our purpose was to estimate protein intake and explore how different levels of protein intake influence metabolic risk factors in Korean older adults.

Methods: Data were obtained from men aged $51-70$ years $(n=1,735)$, men aged $\geq 71$ years $(n=700)$, women aged $51-70$ years $(n=2,305)$, and women aged $\geq 71$ years $(n=957)$. Health and dietary data were obtained from the Korean National Health and Nutrition Examination Survey of 2010-2011.

Results: Relative to the recommended protein intake based on the Dietary Reference Intakes for Koreans, inadequate intake was higher in women and super-aging groups than in others. Women had an increased risk of having metabolic risk factors. After adjustment for age and sex, compared with those in the highest quartile of protein intake levels ( $>1.2 \mathrm{~g}$ protein $/ \mathrm{kg}$ body weight/day), participants in the lowest quartile $(<0.8 \mathrm{~g}$ protein $/ \mathrm{kg}$ body weight/day) had increased odds ratios (ORs) for abdominal obesity (men: OR, 2.67; $95 \%$ confidence interval [Cl], 2.00-3.56; women: OR, 3.42; 95\% Cl, 2.64-4.43), hypertriglyceridemia (men: OR, 1.44; 95\% Cl, 1.08-1.93; women: OR, 1.82; $95 \% \mathrm{Cl}, 1.45-2.29$ ), and high fasting blood glucose (men: OR, 1.41; $95 \% \mathrm{Cl}, 1.07-1.87$; women: OR, 2.03; 95\% Cl, 1.48-2.79).

Conclusion: Protein intake ( $<0.8 \mathrm{~g}$ protein/ $\mathrm{kg}$ body weight/day) lower than the recommend level was associated with a higher risk of metabolic abnormalities in Korean older adults. In particular, lower intake of protein contributed to a higher prevalence of metabolic risk factors in women than in men.

Key words: Protein intake, Metabolic abnormality, Body composition, Adults

\author{
Received March 9, 2017 \\ Reviewed May 16, 2017 \\ Accepted October 30, 2017 \\ *Corresponding author \\ Jaekyung No \\ (iD) \\ https://orcid.org/0000-0003-2433-346X \\ Department of Food and Nutrition, \\ Kyungsung University, 309 Suyeong-ro, \\ Nam-gu, Busan 48434, Korea \\ Tel: +82-51-663-4651 \\ Fax: +82-51-663-4651 \\ E-mail:jkno3@ks.ac.kr
}

\section{INTRODUCTION}

Metabolic syndrome (MS) is closely linked with an increased risk of chronic diseases such as cardiovascular disease and all-cause mortality both in Korea and worldwide. ${ }^{1-3}$ Among Korean adults, the prevalence of MS was $28.1 \%$ in 2001, 29.2\% in 2005, and $31.3 \%$ in $2007 .{ }^{4}$ The prevalence is even higher in the elderly. According to a report ${ }^{5}$, Korea has become a super-aging society like Japan, and the proportion of the elderly has been increasing rapidly, with the elderly projected to account for $14.3 \%$ of the population by 2018 . Therefore, MS is one of the major public health and aging concerns among Korean older adults.

A number of studies have found that impaired glucose metabolism, such as insulin resistance (IR), is the core cause of metabolic risk factors ${ }^{6-8}$, and associations between body composition changes and IR are fundamental to metabolic risk factors. ${ }^{9}$ With aging, body composition changes, and loss of skeletal muscle and/or increased fat mass may increase the risk of functional impairment and chronic metabolic disease. Skeletal muscle produces cytokines and myokines, and is a primary organ for insulin-stimulated glucose utilization..$^{9}$ According to Eckel et al. ${ }^{10}$, an overabundance of fatty acids from high intake of carbohydrates and fat is a major contributor to

Copyright @ 2017 Korean Society for the Study of Obesity

(a) This is an Open Access article distributed under the terms of the Creative Commons Attribution Non-Commercial License (http://creativecommons.org/licenses/by-nc/4.o/) which permits unrestricted non-commercial use, distribution, and reproduction in any medium, provided the original work is properly cited. 
the development of IR. The most efficient strategy to prevent MS in the elderly is to decrease weight by decreasing total caloric, fat, and carbohydrate intake and increasing physical activity. ${ }^{11,12}$ However, the relationship between protein requirements and metabolic risk factors in older adults has not been well explored.

Especially in older adults, for whom progressive loss of muscle mass and increased fat mass are natural phenomena, it is inappropriate to focus on decreased fat and carbohydrate intake to prevent metabolic risk without considering protein-related muscle synthesis. ${ }^{13}$ In addition, many studies have questioned whether protein recommendations for older adults are adequate or not. ${ }^{14,15}$ Adequate protein intake could be a specific intervention to reduce the risk of metabolic risk factors by increasing muscle mass, which could improve insulin sensitivity, particularly in the elderly. From this perspective, it is important to investigate the possibility of insufficient intake of protein in some Korean older adults. Using national data, we estimated protein intake levels/status and explored how suboptimal intake of protein can influence metabolic risk factors in Korean older adults.

\section{METHODS}

\section{Study population}

We examined cross-sectional associations between protein intake and metabolic risk factors in Korean older adults by analysis of data obtained from the Korean National Health and Nutrition Examination Survey (KNHANES) 2010-2011. The protocol of this study was approved by the Research Ethics Review Committee of the Korean Centers for Disease Control and Prevention Institutional Review Board (IRB No. 2010-02CON-21-C and 2011-02CON06-C). All the participants signed the informed consent form. A rolling sampling design involving a complex, stratified, multistage probability-cluster survey of a representative sample of the noninstitutionalized civilian population was used to assess the health and nutritional status of the Korean population. ${ }^{16}$ Subjects in the current cross-sectional study $(n=5,697)$ were men aged $51-70$ years $(\mathrm{n}=1,735)$, men aged $\geq 71$ years $(\mathrm{n}=700)$, women aged $51-70$ years $(\mathrm{n}=2,305)$, and women aged $\geq 71$ years $(\mathrm{n}=957)$ who completed both the health and dietary surveys of the KNHANES.

\section{Procedure}

\section{Assessment of risk factors}

We examined the following metabolic risk factors: central obesity (waist circumference $\geq 90 \mathrm{~cm}$ in men and $\geq 85 \mathrm{~cm}$ in women), body mass index (BMI, $\geq 25 \mathrm{~kg} / \mathrm{m}^{2}$ ), hypertriglyceridemia (blood triglyceride $\geq 150 \mathrm{mg} / \mathrm{dL}$ ), hyperglycemia (fasting plasma glucose $\geq 100 \mathrm{mg} / \mathrm{dL}$ ), HbAlc ( $\geq 7 \%$ ), and total cholesterol ( $\geq 200 \mathrm{mg} /$ $\mathrm{dL})$. BMI of $25 \mathrm{~kg} / \mathrm{m}^{2}$ or higher indicates a status of overweight or obese according to the standards of the International Obesity Task Force, the World Health Organization and the Korean Society for the Study of Obesity. ${ }^{17}$ The equation to calculate BMI is as follows: BMI $\left(\mathrm{kg} / \mathrm{m}^{2}\right)=$ weight $(\mathrm{kg}) \div$ height $(\mathrm{m})^{2}$. To determine how different quantities of protein intake influence metabolic risk factors in Korean older adults, daily protein intake was classified into four levels as follows: less than $0.8 \mathrm{~g}$ protein $/ \mathrm{kg}$ body weight per day, $0.8-1.0 \mathrm{~g}$ protein/ $\mathrm{kg}$ body weight per day, $1.0-1.2 \mathrm{~g}$ protein $/ \mathrm{kg}$ body weight per day, and $1.2 \mathrm{~g}$ protein $/ \mathrm{kg}$ body weight per day or more. We hypothesized that protein intake of $1.2 \mathrm{~g}$ protein $/ \mathrm{kg}$ body weight per day or more would be associated with fewer metabolic risk factors than lower levels of protein intake.

\section{Statistical analyses}

All statistical analyses were conducted using IBM SPSS version 20.0 (IBM Corp., Armonk, NY, USA). Descriptive statistics and the percentage of the population with abnormalities were used to test for protein intake-related factors and biochemical parameters of metabolic risk factors by both sex and age. Values are reported as mean \pm standard error. Logistic regression analyses were used to calculate odds ratio (OR) with $95 \%$ confidence interval (CI) for the different levels of protein intake and metabolic abnormality factors after adjusting for age and sex. Statistical significance was accepted at $P<0.05$.

\section{RESULTS}

Table 1 summarizes the protein intake and percentage of the population below the Dietary Reference Intakes for Koreans. Mean grams per day $(\mathrm{g} /$ day) of protein intake was lower in women in the oldest age group (aged $\geq 71$ years) and the 51-70 age group ( $41.53 \pm 0.88$ and $56.28 \pm 0.79$, respectively) than men in these two 
Table 1. Usual protein intake among Korean elderly and the percentage of the population below the estimated average requirement*

\begin{tabular}{|c|c|c|c|c|c|c|c|c|}
\hline \multirow{2}{*}{ Protein measure } & & \multicolumn{6}{|c|}{ Percentile } & \multirow{2}{*}{$\%<$ EAR } \\
\hline & & Mean \pm SE & 5th & 25th & 50th & 75th & 95th & \\
\hline \multicolumn{8}{|l|}{ Gram per day } & - \\
\hline \multirow[t]{2}{*}{ Men } & $51-70 \mathrm{yr}$ & $82.66 \pm 1.25$ & 34.43 & 53.98 & 74.63 & 100.16 & 153.54 & \\
\hline & $\geq 71 \mathrm{yr}$ & $57.76 \pm 1.39$ & 24.40 & 39.63 & 52.78 & 70.95 & 114.18 & \\
\hline \multirow[t]{2}{*}{ Women } & $51-70$ yr & $56.28 \pm 0.79$ & 23.25 & 38.11 & 51.70 & 69.00 & 107.80 & \\
\hline & $\geq 71 \mathrm{yr}$ & $41.53 \pm 0.88$ & 16.87 & 27.82 & 38.83 & 53.75 & 82.51 & \\
\hline \multicolumn{8}{|l|}{ \% Energy } & - \\
\hline \multirow[t]{2}{*}{ Men } & $51-70 \mathrm{yr}$ & $13.91 \pm 0.12$ & 8.73 & 11.42 & 13.57 & 16.01 & 20.92 & \\
\hline & $\geq 71 \mathrm{yr}$ & $12.66 \pm 0.17$ & 8.16 & 10.37 & 12.30 & 14.88 & 19.43 & \\
\hline \multirow[t]{2}{*}{ Women } & $51-70 \mathrm{yr}$ & $13.42 \pm 0.11$ & 8.60 & 10.89 & 13.05 & 15.29 & 20.08 & \\
\hline & $\geq 71 \mathrm{yr}$ & $12.04 \pm 0.13$ & 7.93 & 9.72 & 11.56 & 13.81 & 18.58 & \\
\hline \multicolumn{9}{|c|}{ Gram per kg body weight } \\
\hline \multirow[t]{2}{*}{ Men } & $51-70 \mathrm{yr}$ & $1.24 \pm 0.02$ & 0.52 & 0.83 & 1.12 & 1.52 & 2.32 & 22.7 \\
\hline & $\geq 71 \mathrm{yr}$ & $0.96 \pm 0.03$ & 0.41 & 0.64 & 0.87 & 1.18 & 1.89 & 44.2 \\
\hline \multirow[t]{2}{*}{ Women } & $51-70 y r$ & $0.98 \pm 0.01$ & 0.41 & 0.64 & 0.90 & 1.21 & 1.94 & 42.4 \\
\hline & $\geq 71 \mathrm{yr}$ & $0.79 \pm 0.02$ & 0.31 & 0.54 & 0.74 & 1.01 & 1.59 & 60.5 \\
\hline
\end{tabular}

*Values were obtained from men aged $51-70 \mathrm{yr}, \mathrm{n}=1,735$; men aged $\geq 71 \mathrm{yr}, \mathrm{n}=700$; women aged $51-70 \mathrm{yr}, \mathrm{n}=2,305$; women aged $\geq 71 \mathrm{yr}, \mathrm{n}=957$. $\mathrm{SE}$, standard error; EAR, estimated average requirement.

age groups (57.76 \pm 1.39 and $82.66 \pm 1.25$, respectively). Typical mean $\mathrm{g} / \mathrm{kg}$ body weight protein intake and percentage energy intake showed the same patterns among age and sex subgroups, as did the $\mathrm{g} /$ day amount of protein intake. The percentage (\%) of energy from protein did not vary much by sex or age (men: $13.91 \pm$ $0.12,12.66 \pm 0.17$ vs. women: $13.42 \pm 0.11,12.04 \pm 0.13$ for those aged 51-70 and aged $\geq 71$, respectively). Table 2 shows the metabolic risk factors and abnormality estimates by percentage of the population according to sex and age. Mean waist circumference $(\mathrm{cm})$ measurements, serum triglycerides $(\mathrm{mg} / \mathrm{dL})$, and glucose $(\mathrm{mg} / \mathrm{dL})$ levels were lower in women than men. However, mean BMI (kg/ $\mathrm{m}^{2}$ ) and $\mathrm{HbAlc}(\%)$ levels were higher in women than men.

Logistic regression results and OR (95\% CI) for metabolic risk factors according to protein intake level are presented in Table 3. Risk of developing a waist abnormality was significantly higher in the lowest protein intake group ( $<0.8 \mathrm{~g}$ protein $/ \mathrm{kg}$ body weight/ day) in both men (OR, 2.67; 95\% CI, 2.00-3.56; $P<0.001)$ and women (OR, 3.42; 95\% CI, 2.64-4.43; $P<0.001$ ). The group with the lowest protein intake ( $<0.8 \mathrm{~g}$ protein/ $\mathrm{kg}$ body weight/day) had a significantly higher likelihood of risk factors for BMI abnormalities in both men (OR, 1.90; 95\% CI, 1.42-2.54; $P<0.001)$ and women (OR, 2.72; 95\% CI, 2.07-3.58; $P<0.001)$. There was a significant association between the lowest protein intake group
( $<0.8 \mathrm{~g}$ protein $/ \mathrm{kg}$ body weight/day) and risk of triglycerides abnormality in both men (OR, 1.44; 95\% CI, 1.08-1.93; $P<0.05$ ) and women (OR, 1.82; 95\% CI, 1.45-2.29; $P<0.001)$. The group with the lowest protein intake ( $<0.8 \mathrm{~g}$ protein $/ \mathrm{kg}$ body weight/ day) had a significantly higher likelihood of elevated fasting blood glucose in both men (OR, 1.41; 95\% CI, 1.07-1.87; $P<0.05)$ and women (OR, 2.03; 95\% CI, 1.48-2.79; $P<0.001$ ). The group with the lowest protein intake ( $<0.8 \mathrm{~g}$ protein $/ \mathrm{kg}$ body weight/day) were also significantly more likely to have an elevated $\mathrm{HbAlc}$ level in both men (OR, 1.86; 95\% CI, 1.27-2.72; $P<0.01)$ and women (OR, 1.78; 95\% CI, 1.19-2.68; $P<0.01$ ). Total cholesterol was not associated with protein intake.

\section{DISCUSSION}

We investigated the association between dietary intake of protein and metabolic risk factors in Korean older adults based on analysis of KNHANES data. The study was conducted under the assumption that insufficient protein intake could significantly impact metabolic risk factors and that the currently recommend protein intake levels are not sufficient for Korean older adults. To improve basic knowledge about healthy aging, it is important to explore how different amounts of protein intake influence metabolic risk factors in 
Table 2. Metabolic risk factors among Korean elderly and percentage of the population*

\begin{tabular}{|c|c|c|c|c|c|c|c|c|}
\hline \multirow{2}{*}{ Metabolic risk factor } & & \multirow{2}{*}{ Mean \pm SE } & \multicolumn{5}{|c|}{ Percentile } & \multirow{2}{*}{$\%<$ Criteria } \\
\hline & & & 5th & 25th & 50th & 75th & 95th & \\
\hline \multicolumn{9}{|c|}{ Waist circumference $(\mathrm{cm})^{\ddagger}$} \\
\hline \multirow[t]{2}{*}{ Men } & $51-70 \mathrm{yr}$ & $85.56 \pm 0.25$ & 71.40 & 80.58 & 85.50 & 90.93 & 98.20 & 28.30 \\
\hline & $\geq 71 \mathrm{yr}$ & $83.99 \pm 0.49$ & 67.45 & 77.50 & 84.70 & 91.25 & 99.15 & 29.40 \\
\hline \multirow[t]{2}{*}{ Women } & $51-70$ yr & $82.32 \pm 0.27$ & 68.00 & 76.00 & 82.05 & 88.20 & 97.07 & 37.40 \\
\hline & $\geq 71 \mathrm{yr}$ & $82.82 \pm 0.42$ & 65.64 & 75.80 & 82.40 & 89.30 & 99.12 & 41.80 \\
\hline \multicolumn{9}{|c|}{ Body mass index $\left(\mathrm{kg} / \mathrm{m}^{2}\right)^{\mathrm{s}}$} \\
\hline \multirow[t]{2}{*}{ Men } & $51-70 y r$ & $23.89 \pm 0.08$ & 19.10 & 22.00 & 23.89 & 25.67 & 28.57 & 35.60 \\
\hline & $\geq 71 \mathrm{yr}$ & $22.71 \pm 0.14$ & 18.00 & 20.71 & 22.65 & 24.89 & 27.95 & 23.50 \\
\hline \multirow[t]{2}{*}{ Women } & $51-70 \mathrm{yr}$ & $24.36 \pm 0.08$ & 19.56 & 22.21 & 24.10 & 26.23 & 29.82 & 39.20 \\
\hline & $\geq 71 \mathrm{yr}$ & $23.88 \pm 0.16$ & 18.26 & 21.55 & 23.71 & 26.04 & 30.17 & 34.50 \\
\hline \multicolumn{9}{|c|}{ Serum triglycerides $(\mathrm{mg} / \mathrm{dL})^{\| \prime}$} \\
\hline \multirow[t]{2}{*}{ Men } & $51-70 \mathrm{yr}$ & $169.90 \pm 4.16$ & 52.00 & 89.00 & 131.00 & 195.00 & 361.00 & 43.00 \\
\hline & $\geq 71 \mathrm{yr}$ & $130.28 \pm 4.01$ & 49.00 & 74.75 & 109.00 & 155.00 & 287.00 & 28.10 \\
\hline \multirow[t]{2}{*}{ Women } & $51-70 y r$ & $134.16 \pm 2.23$ & 50.00 & 80.00 & 113.00 & 166.00 & 286.00 & 31.00 \\
\hline & $\geq 71 \mathrm{yr}$ & $146.27 \pm 3.76$ & 54.60 & 87.50 & 123.00 & 172.50 & 289.70 & 35.80 \\
\hline \multicolumn{9}{|l|}{ Glucose (mg/dL) } \\
\hline \multirow[t]{2}{*}{ Men } & $51-70 \mathrm{yr}$ & $106.13 \pm 0.83$ & 82.00 & 91.00 & 98.00 & 110.00 & 161.00 & 25.10 \\
\hline & $\geq 71 \mathrm{yr}$ & $102.11 \pm 1.14$ & 82.00 & 90.00 & 97.00 & 109.00 & 145.00 & 20.70 \\
\hline \multirow[t]{2}{*}{ Women } & $51-70 \mathrm{yr}$ & $99.54 \pm 0.62$ & 81.00 & 88.00 & 94.00 & 103.00 & 137.00 & 15.50 \\
\hline & $\geq 71 \mathrm{yr}$ & $104.10 \pm 1.09$ & 81.00 & 89.00 & 97.00 & 108.00 & 149.00 & 23.20 \\
\hline \multicolumn{9}{|l|}{$\operatorname{HbA1c}(\%)^{* *}$} \\
\hline \multirow[t]{2}{*}{ Men } & $51-70 \mathrm{yr}$ & $6.18 \pm 0.05$ & 5.10 & 5.50 & 5.80 & 6.50 & 8.60 & 23.00 \\
\hline & $\geq 71 \mathrm{yr}$ & $6.16 \pm 0.07$ & 5.20 & 5.50 & 5.90 & 6.50 & 8.38 & 21.60 \\
\hline \multirow[t]{2}{*}{ Women } & $51-70 y r$ & $6.08 \pm 0.04$ & 5.20 & 5.60 & 5.80 & 6.20 & 8.20 & 17.30 \\
\hline & $\geq 71 \mathrm{yr}$ & $6.22 \pm 0.05$ & 5.20 & 5.60 & 5.90 & 6.48 & 8.70 & 22.30 \\
\hline \multicolumn{9}{|c|}{ Total cholesterol $(\mathrm{mg} / \mathrm{dL})^{1+}$} \\
\hline \multirow[t]{2}{*}{ Men } & $51-70 \mathrm{yr}$ & $188.82 \pm 1.10$ & 131.00 & 164.00 & 187.00 & 211.00 & 250.00 & 36.10 \\
\hline & $\geq 71 \mathrm{yr}$ & $179.76 \pm 1.65$ & 124.00 & 157.00 & 177.00 & 200.00 & 240.00 & 25.50 \\
\hline \multirow[t]{2}{*}{ Women } & $51-70 \mathrm{yr}$ & $203.35 \pm 1.07$ & 144.00 & 178.00 & 202.00 & 226.00 & 264.00 & 51.80 \\
\hline & $\geq 71 \mathrm{yr}$ & $198.63 \pm 1.62$ & 140.00 & 172.00 & 196.00 & 221.00 & 264.70 & 45.90 \\
\hline
\end{tabular}

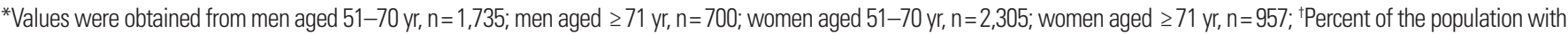
metabolic abnormalities; ${ }^{\ddagger}$ Criteria: waist circumference, $\geq 90 \mathrm{~cm}$ in men and $\geq 85 \mathrm{~cm}$ in women; ${ }^{\S}$ Criteria: $\geq 25 \mathrm{~kg} / \mathrm{m}^{2}$; "Criteria of hypertriglyceridemia: $\geq 150 \mathrm{mg} / \mathrm{dL}$; ${ }^{~} \mathrm{Criteria}$ of hyperglycemia (fasting plasma glucose): $\geq 110 \mathrm{mg} / \mathrm{dL}^{*}{ }^{* *}$ Criteria: $\geq 7 \%$; ${ }^{\text {t+C} C r i t e r i a: ~} \geq 200 \mathrm{mg} / \mathrm{dL}$.

SE, standard error.

the elderly. Lim et al. ${ }^{4}$ reported that the prevalence of MS in Korea has increased more rapidly than in the USA, and the Ministry of Health and Welfare ${ }^{18}$ reported that it increased to $46.3 \%$ among elderly aged 65 and over of both genders in Korea. Adequate intake of protein, which could improve IR by maintaining muscle mass, could be a strategy for preventing diseases in seniors. ${ }^{19}$ According to $\mathrm{Lu}$ et al.s research ${ }^{20}$, low muscle mass and a form of obesity called sarcopenia ${ }^{21}$ are associated with MS in the American elderly. In the present study, we found evidence of associations between protein intake and metabolic risk factors in both genders, and women were more at risk than men. The same findings emerged in Lim et al.s study ${ }^{4}$, in which the prevalence of MS in young people aged 20-49 years was higher in men than women, but for the elderly (aged $\geq 50$ years), it increased more notably in women than men. This suggests that gender-specific treatments should be provided in older adults to prevent MS, such as different amounts of protein intake.

Our analysis showed that the ranges of suboptimal protein intake differed according to gender and metabolic risk factors. As protein intake decreased to less than $1.2 \mathrm{~g} / \mathrm{kg}$, abnormalities in waist cir- 
Table 3. ORs for metabolic risk factors according to protein intake ( $m e n=2,435$, women $=3,262$ )

\begin{tabular}{|c|c|c|c|c|}
\hline \multirow{2}{*}{ Variable } & \multicolumn{4}{|c|}{ Protein intake (g/body weight $[\mathrm{kg}] /$ day) } \\
\hline & $>1.2$ & $1.0-1.2$ & $0.8-1.0$ & $<0.8$ \\
\hline \multicolumn{5}{|l|}{ Abdominal obesity* } \\
\hline Men $\geq 51 \mathrm{yr}$ & 1.00 & $1.91(1.37-2.67)^{\S}$ & $1.49(1.04-2.13)^{\dagger}$ & $2.67(2.00-3.56)^{8}$ \\
\hline Women $\geq 51 \mathrm{yr}$ & 1.00 & $1.61(1.19-2.18)^{\ddagger}$ & $2.13(1.60-2.83)^{\S}$ & $3.42(2.64-4.43)^{8}$ \\
\hline \multicolumn{5}{|c|}{ Body mass index $\geq 25 \mathrm{~kg} / \mathrm{m}^{2}$} \\
\hline Men $\geq 51 \mathrm{yr}$ & 1.00 & $1.56(1.13-2.14)^{\ddagger}$ & $1.51(1.07-2.11)^{\dagger}$ & $1.90(1.42-2.54)^{\S}$ \\
\hline Women $\geq 51 \mathrm{yr}$ & 1.00 & $1.49(1.07-2.08)^{\dagger}$ & $1.88(1.37-2.58)^{5}$ & $2.72(2.07-3.58)^{5}$ \\
\hline \multicolumn{5}{|c|}{ Triglycerides $\geq 150 \mathrm{mg} / \mathrm{dL}$} \\
\hline Men $\geq 51 \mathrm{yr}$ & 1.00 & $1.29(0.91-1.82)$ & $1.17(0.87-1.56)$ & $1.44(1.08-1.93)^{\dagger}$ \\
\hline Women $\geq 51 \mathrm{yr}$ & 1.00 & $1.34(0.95-1.88)$ & $1.76(1.30-2.38)^{\S}$ & $1.82(1.45-2.29)^{5}$ \\
\hline \multicolumn{5}{|c|}{ Total cholesterol $\geq 200 \mathrm{mg} / \mathrm{dL}$} \\
\hline Men $\geq 51 \mathrm{yr}$ & 1.00 & $1.16(0.84-1.60)$ & $1.13(0.82-1.57)$ & $1.02(0.78-1.34)$ \\
\hline Women $\geq 51 \mathrm{yr}$ & 1.00 & $0.98(0.72-1.34)$ & $1.03(0.75-1.42)$ & $0.95(0.75-1.20)$ \\
\hline \multicolumn{5}{|c|}{ High fasting blood glucose $\geq 110 \mathrm{mg} / \mathrm{dL}$} \\
\hline Men $\geq 51 \mathrm{yr}$ & 1.00 & $1.12(0.78-1.61)$ & $1.28(0.90-1.80)$ & $1.41(1.07-1.87)^{\dagger}$ \\
\hline Women $\geq 51 \mathrm{yr}$ & 1.00 & $1.40(0.92-2.14)$ & $1.52(1.01-2.28)^{\dagger}$ & $2.03(1.48-2.79)^{8}$ \\
\hline \multicolumn{5}{|l|}{$\mathrm{HbA} 1 \mathrm{c} \geq 7 \%$} \\
\hline Men $\geq 51 \mathrm{yr}$ & 1.00 & $1.19(0.70-2.01)$ & $1.59(1.00-2.53)$ & $1.86(1.27-2.72)^{\ddagger}$ \\
\hline Women $\geq 51 \mathrm{yr}$ & 1.00 & $1.34(0.79-2.26)$ & $1.58(0.96-2.60)$ & $1.78(1.19-2.68)^{\neq}$ \\
\hline
\end{tabular}

Values are presented as OR (95\% confidence interval). After adjustment for age, sex, statistical significance was accepted at $<0.05$.

${ }^{*}$ Waist circumference, $\geq 90 \mathrm{~cm}$ in men and $\geq 85 \mathrm{~cm}$ in women; ${ }^{\dagger} P<0.05 ;{ }^{\ddagger} P<0.01 ;{ }^{\S} P<0.001$.

$\mathrm{OR}$, odds ratio.

cumference and BMI increased significantly more rapidly in women than men. Aging-related hormonal changes influence biological changes and functions. In postmenopausal women, as age increases, body composition changes; there is $1 \%-2 \%$ muscle mass loss and fat mass increase due to reduced estrogen secretion. ${ }^{22}$ However, the increase in fat mass may stop or decline as women age further. ${ }^{22}$ According to Lu et $\mathrm{al}^{20}{ }^{20}$ the group with sarcopenic obesity showed a higher risk for MS than other groups and this was independently associated with individual components of MS including waist circumference, high-density lipoprotein cholesterol, triglyceride, and fasting glucose levels. In other research on protein and skeletal muscle, insufficient protein intake was associated with various abnormal body composition phenotypes. ${ }^{23}$ High protein intake is associated with reduced body weight, fat mass, and triglyceride level and increased muscle mass and resting energy expenditure. ${ }^{24}$ Clearly, too much protein intake in elderly individuals with poor kidney function is also not desirable. The risks of having triglycerides and fasting glucose level abnormalities were significantly higher when protein intake was less than $0.8 \mathrm{~g} / \mathrm{kg}$ body weight per day compared to higher daily protein intake levels.
Our findings suggest that $1.2 \mathrm{~g}$ protein/ $\mathrm{kg}$ body weight per day or more of protein consumption could reduce metabolic risk. How much protein is appropriate for older adults? Currently, the protein intake levels considered to be adequate for seniors vary among studies. A substantial amount of evidence suggests that the recommended dietary allowances (RDA) of $0.8 \mathrm{~g} / \mathrm{kg}$ of protein per day is not optimal for muscle and bone health in elderly people in the United States. In the United States, $40 \%$ of the elderly aged $\geq 70$ years have been shown to have sufficient protein intake according to the recommended criteria. ${ }^{19}$ Among the Korean elderly, typical protein intake is lower than among the American elderly. ${ }^{25}$ In the present study, the prevalence of intake of less than $0.8 \mathrm{~g}$ protein $/ \mathrm{kg}$ body weight per day was higher in women than in men, which may have contributed to the higher prevalence of MS in women than men. Additionally, more people in the older age group were found to have poor protein intake than those in the younger age group. When we investigated mean protein intake by sex and age, all groups except the oldest women had a protein intake of at least 0.8 g protein $/ \mathrm{kg}$ body weight per day. However, almost half of the population are likely to have insufficient protein intake because of de- 
creased relaxation of the fundus, increased release of cholecystokinin and leptin, reduced appetite due to changes in taste and smell, social changes, and economic limits associated with aging. ${ }^{26,27}$ Therefore, for the elderly, more individual and specific criteria and training are needed.

Research on nitrogen balance in the elderly conducted by Kim et al. ${ }^{28}$ showed that intake of $0.8 \mathrm{~g}$ protein $/ \mathrm{kg}$ body weight per day was not sufficient for the elderly, and those authors suggested that protein intake be increased to $1.14 \mathrm{~g} / \mathrm{kg}$ body weight per day. Research by Dutheil et al. ${ }^{29}$ conducted on 28 average people with MS aged 61.8 years revealed that the lower threshold of protein intake to maintain blood protein homeostasis was $1.2 \mathrm{~g}$ protein $/ \mathrm{kg}$ body weight per day. Another study reported a required intake level of approximately $0.9 \mathrm{~g}$ protein $/ \mathrm{kg}$ body weight per day. ${ }^{30}$ The recommended intake of dietary protein based on achieving nitrogen equilibrium varies according to age because energy requirements decline with age. It was originally $1.0 \mathrm{~g}$ protein $/ \mathrm{kg}$ body weight per day until the $1980 \mathrm{RDA}$, but it was thereafter decreased to $0.8 \mathrm{~g}$ protein/kg body weight per day, which is the current RDA for all adults (aged $\geq 19$ years). A moderate increase in daily protein intake to 1.0 to $1.3 \mathrm{~g}$ protein $/ \mathrm{kg}$ might be needed to lower energy intake, improve IR function, and reduce the progressive loss of muscle mass in elderly individuals. ${ }^{15,31}$

Our study has both strengths and limitations, which could be addressed by additional investigations. One limitation was the use of 24-hour recall data to estimate nutrition intake. Memory errors in older adults may have resulted in over- or under-reporting of protein intake, which may have impacted the accuracy of our data. In addition, it was difficult to accurately assess individuals' daily protein intake. Another limitation was that the cross-sectional design of this study precluded our ability to make causal inferences between level of protein intake and metabolic risk factors. Determination, treatment, and the presence of MS in the KNHANES should be explored in the future studies. We could not control for all epigenetic influences; thus, these results need to be confirmed by additional studies with longitudinal designs if the results of this study are to be generalized. Advantages of our study include the fact that we explored the relationships between defined optimal levels of dietary protein and metabolic risk factors in a large number of Korean older individuals whereas most previous studies on strategies to prevent MS have been conducted in Western countries, even though the prevalence of MS has been increasing rapidly and steadily in Korea. Additionally, only a few studies have focused on protein intake level and MS among older adults in Korea.

In conclusion, our findings suggest that elderly women who eat less than $0.8 \mathrm{~g}$ protein $/ \mathrm{kg}$ body weight per day have higher metabolic risk factors than elderly men who eat less than $0.8 \mathrm{~g}$ protein/ $\mathrm{kg}$ body weight per day. Greater emphasis should be placed on a protein intake over $0.8 \mathrm{~g}$ protein $/ \mathrm{kg}$ body weight to decrease metabolic risk, and efforts should be made to educate older adults about the importance of protein intake and to provide them with proteinrich foods. Most Korean older adults appeared to consume more than enough protein in their daily diets when compared with the mean value, but among them, specific people were at risk for being protein-deficient, including older women and very old individuals. Therefore, the current recommendations for protein intake for optimal health in Korean older adults should be reconsidered to potentially decrease metabolic risk in Korean older adults.

\section{CONFLICTS OF INTEREST}

The authors declare no conflict of interest.

\section{ACKNOWLEDGMENTS}

This research was funded by the Kyungsung University, Busan, Korea in 2016 (No. 2016092).

$\mathrm{CO}$ designed and carried out the study, analyzed the data, and drafted the manuscript. JN contributed to study design and article revision. All authors read and approved the final manuscript.

\section{REFERENCES}

1. Ford ES. Risks for all-cause mortality, cardiovascular disease, and diabetes associated with the metabolic syndrome: a summary of the evidence. Diabetes Care 2005;28:1769-78.

2. Khang YH, Cho SI, Kim HR. Risks for cardiovascular disease, stroke, ischaemic heart disease, and diabetes mellitus associated with the metabolic syndrome using the new harmonised definition: findings from nationally representative longitudinal 
data from an Asian population. Atherosclerosis 2010;213:57985.

3. Kavanagh A, Bentley RJ, Turrell G, Shaw J, Dunstan D, Subramanian SV. Socioeconomic position, gender, health behaviours and biomarkers of cardiovascular disease and diabetes. Soc Sci Med 2010;71:1150-60.

4. Lim S, Shin H, Song JH, Kwak SH, Kang SM, Won Yoon J, et al. Increasing prevalence of metabolic syndrome in Korea: the Korean National Health and Nutrition Examination Survey for 1998-2007. Diabetes Care 2011;34:1323-8.

5. Statistics Korea. 2017 Elderly people statistics [Internet]. Daejeon: Korean Statistical Information Service; 2017 [cited 2017 Nov 22]. Available from: http://analysis.kostat.go.kr/publicsmodel

6. Roberts CK, Hevener AL, Barnard RJ. Metabolic syndrome and insulin resistance: underlying causes and modification by exercise training. Compr Physiol 2013;3:1-58.

7. Lee S, Choi S, Kim HJ, Chung YS, Lee KW, Lee HC, et al. Cutoff values of surrogate measures of insulin resistance for metabolic syndrome in Korean non-diabetic adults. J Korean Med Sci 2006;21:695-700.

8. Potenza MV, Mechanick JI. The metabolic syndrome: definition, global impact, and pathophysiology. Nutr Clin Pract 2009;24:560-77.

9. Stump CS, Henriksen EJ, Wei Y, Sowers JR. The metabolic syndrome: role of skeletal muscle metabolism. Ann Med 2006; $38: 389-402$

10. Eckel RH, Grundy SM, Zimmet PZ. The metabolic syndrome. Lancet 2005;365:1415-28.

11. Andersen CJ, Fernandez ML. Dietary strategies to reduce metabolic syndrome. Rev Endocr Metab Disord 2013;14:241-54.

12. Onat A. Metabolic syndrome: nature, therapeutic solutions and options. Expert Opin Pharmacother 2011;12:1887-900.

13. Rosenberg IH. Sarcopenia: origins and clinical relevance. J Nutr 1997;127(Suppl 5):990S-991S.

14. Volpi E, Campbell WW, Dwyer JT, Johnson MA, Jensen GL, Morley JE, et al. Is the optimal level of protein intake for older adults greater than the recommended dietary allowance? J Gerontol A Biol Sci Med Sci 2013;68:677-81.

15. Pedersen AN, Cederholm T. Health effects of protein intake in healthy elderly populations: a systematic literature review. Food Nutr Res 2014;58:23364.

16. Ministry of Health and Welfare. Korea National Health and Nutrition Examination Survey [Internet]. Cheongju: Korea Centers for Disease Control and Prevention; 2011 [cited 2017 Nov 2]. Available from: https://knhanes.cdc.go.kr

17. Oh SW. Obesity and metabolic syndrome in Korea. Diabetes Metab J 2011;35:561-6.

18. Ministry of Health and Welfare. Korea National Health and Nutrition Examination Survey report (KNHANES III) [Internet]. Cheongju: Korea Centers for Disease Control and Prevention; 2005 [cited 2017 Nov 2]. Available from: https:// knhanes.cdc.go.kr/knhanes/index.do

19. Paddon-Jones D, Rasmussen BB. Dietary protein recommendations and the prevention of sarcopenia. Curr Opin Clin Nutr Metab Care 2009; 12:86-90.

20. Lu CW, Yang KC, Chang HH, Lee LT, Chen CY, Huang KC. Sarcopenic obesity is closely associated with metabolic syndrome. Obes Res Clin Pract 2013;7:e301-7.

21. Lim S, Kim JH, Yoon JW, Kang SM, Choi SH, Park YJ, et al. Sarcopenic obesity: prevalence and association with metabolic syndrome in the Korean Longitudinal Study on Health and Aging (KLoSHA). Diabetes Care 2010;33:1652-4.

22. Kelly TL, Wilson KE, Heymsfield SB. Dual energy X-ray absorptiometry body composition reference values from NHANES. PLoS One 2009;4:e7038.

23. Thalacker-Mercer AE, Fleet JC, Craig BA, Carnell NS, Campbell WW. Inadequate protein intake affects skeletal muscle transcript profiles in older humans. Am J Clin Nutr 2007;85: 1344-52.

24. Wycherley TP, Moran LJ, Clifton PM, Noakes M, Brinkworth GD. Effects of energy-restricted high-protein, low-fat compared with standard-protein, low-fat diets: a meta-analysis of randomized controlled trials. Am J Clin Nutr 2012;96:128198.

25. Lee YH, Lee J, Kim MT, Han HR. In-depth assessment of the nutritional status of Korean American elderly. Geriatr Nurs 2009;30:304-11

26. Chapman IM, MacIntosh CG, Morley JE, Horowitz M. The anorexia of ageing. Biogerontology 2002;3:67-71. 
27. Waters DL, Baumgartner RN, Garry PJ, Vellas B. Advantages of dietary, exercise-related, and therapeutic interventions to prevent and treat sarcopenia in adult patients: an update. Clin Interv Aging 2010;5:259-70.

28. Kim JS, Wilson JM, Lee SR. Dietary implications on mechanisms of sarcopenia: roles of protein, amino acids and antioxidants. J Nutr Biochem 2010;21:1-13.

29. Dutheil F, Lac G, Courteix D, Doré E, Chapier R, Roszyk L, et al. Treatment of metabolic syndrome by combination of physical activity and diet needs an optimal protein intake: a randomized controlled trial. Nutr J 2012;11:72.

30. Paddon-Jones D, Short KR, Campbell WW, Volpi E, Wolfe RR. Role of dietary protein in the sarcopenia of aging. Am J Clin Nutr 2008;87:1562S-1566S.

31. Bauer J, Biolo G, Cederholm T, Cesari M, Cruz-Jentoft AJ, Morley JE, et al. Evidence-based recommendations for optimal dietary protein intake in older people: a position paper from the PROT-AGE Study Group. J Am Med Dir Assoc 2013;14: 542-59. 